\title{
Endothelial progenitor cells and vascular endothelial growth factor in patients with Takayasu's arteritis
}

\author{
Luiz Samuel Gomes Machado* (D), Ana Cecilia Diniz Oliveira, Patricia Semedo-Kuriki, \\ Alexandre Wagner Silva de Souza and Emilia Inoue Sato
}

\begin{abstract}
Background: Endothelial progenitor cells (EPCS) are responsible for endothelial damage repair. Takayasu's arteritis (TA) is a chronic inflammatory disease that affects large vessels. The aim of the study was to evaluate the number of EPCs and the levels of vascular endothelial growth factor (VEGF) and the relationship of these variables in patients with TA.

Methods: Thirty women with TA and 30 healthy controls were included. EPCS were assessed by flow cytometry and cell culture and VEGF quantification was performed by commercial ELISA kits.

Results: Ages of patients and controls were similar. The number of EPCs in patients and controls (median (interquartile range) were $0.0073 \%(0.0081 \%)$ vs. $0.0062 \%(0.0089 \%), p=0.779$ by flow cytometry and 27.0 (42.3) colony forming units (CFUs) vs. 27.0 (20.5) CFUs, $p=0.473$ by cells culture, respectively. VEGF levels in patients and controls was 274.5 (395.5) pg/ml vs. 243.5 (255.3) pg/ml, $p=0.460$. There was no difference in the number of EPCs and VEGF level between patients with active and inactive disease. There was a tendency of the number of angioblast-like EPCs in patients taking anti-TNFs to be higher; and in patients using methotrexate to be lower.

Conclusion: No significant difference was found in the quantification of EPCS and VEGF levels in TA patients compared to controls, and no difference was observed between patients with active and inactive disease.
\end{abstract}

Keywords: Endothelial cells, Vascular endothelial growth factor, Takayasu's arteritis

\section{Background}

Takayasu's arteritis (TA) is a chronic granulomatous vasculitis that affects mainly large vessels as aorta and its branches. TA patients also present premature atherosclerosis [1-4], as reported in other inflammatory rheumatic diseases $[5,6]$. The pathogenesis of atherosclerosis in this arteritis is likely multifactorial and may be related to inflammatory process of vessels, chronic systemic inflammation and increased traditional cardiovascular risk factors $[3,7,8]$. In some diseases such as systemic lupus erythematosus (SLE) and rheumatoid arthritis (RA), premature atherosclerosis is explained in part by decreased levels of endothelial progenitor cells (EPCs) [9-11].

\footnotetext{
* Correspondence: luizmachado67@gmail.com

Rheumatology Division, Escola Paulista de Medicina UNIFESP (Universidade Federal de São Paulo), Rua Doutor Diogo de Faria, 561, apt 12, Vila, Clementin São Paulo-SP CEP: 04037-000, Brazil
}

The EPCs are bone marrow-derived cells that contribute to the reendothelialization of injured vessels, as well as for neovascularization after ischemic injury [12]. These cells are rare [13] and are considered independent predictors of morbidity and mortality in patients with cardiovascular disease [14]. There are two main types of EPCs: angioblast-like EPCs, as assessed by flow cytometry and monocytic EPCs as measured by colony forming units (CFUs) in cell culture [13]. VEGF and stromal cell-derived factor-1 (SDF-1) are hypoxia-induced oxygen-sensitive cytokines [15] and play a key role in the mobilization of EPCs from the bone marrow, maturing these into mature endothelial cells and targeting to sites with ischemic tissue $[16,17]$.

Studies have shown traditional cardiovascular risk factors reduce the count of EPCs [18-21] while medication as statins [22] and angiotensin converting enzyme inhibitors [23],

(c) The Author(s). 2018 Open Access This article is distributed under the terms of the Creative Commons Attribution 4.0 International License (http://creativecommons.org/licenses/by/4.0/), which permits unrestricted use, distribution, and reproduction in any medium, provided you give appropriate credit to the original author(s) and the source, provide a link to the Creative Commons license, and indicate if changes were made. The Creative Commons Public Domain Dedication waiver (http://creativecommons.org/publicdomain/zero/1.0/) applies to the data made available in this article, unless otherwise stated. 
neoplastic diseases [24, 25] and aerobic activity [26] increase the count of EPCs.

In relation to rheumatic diseases, most studies have shown a smaller number of EPCs in patients than controls in RA [9, 27, 28], SLE [10, 11, 29-31], thromboangiitis obliterans [32], ANCA-associated vasculitis [33, 34], Kawasaki disease [35] and Behçet's disease [36]. On the contrary, most studies in patients with systemic sclerosis (SSc) showed a greater number of EPCs when compared to controls [37-42].

In 2014, Dogan et al. published the first study evaluating EPCs in TA patients in Turkey and found no significant difference between TA and controls. However, the number of EPCs measured by flow cytometry in patients with active disease was higher than healthy control. Similar results were found for VEGF level [43].

In analogy to other inflammatory rheumatic diseases, we hypothesized that EPCs could also be involved in the physio pathogenesis of TA. The aim of the study was to quantify both angioblast-like and monocytic EPCs and VEGF levels in Brazilian patients with TA, as well to assess the number of EPCs and VEGF levels in relation to disease activity, presence of hypertension and dyslipidemia, and the use of medications.

\section{Methods}

This was a cross-sectional study carried out at the Federal University of São Paulo/Hospital São Paulo. All participants signed the consent form approved by the Ethics Committee of the institution. Participants were 30 women with TA, aged between 18 and 50 years, who met the classification criteria for TA of the American College of Rheumatology [44]. The control group consisted of 30 female healthy volunteers matched for age. We excluded patients who were current smokers, individuals with diabetes, end-stage kidney disease, coronary disease, infection, malignancy, with another autoimmune rheumatic disease or who had used cyclophosphamide until three months before the study.

TA activity was assessed by criteria of the National Institute of Health (Kerr' criteria) 1994 [45]. Thirty-five mL of peripheral blood was collected from all participants for cells count, erythrocyte sedimentation rate (ESR), creatinine, glucose and serum cholesterol and triglycerides, as well as to quantify angioblast-like and monocytic EPCs and to measure VEGF levels.

\section{Quantification of angioblast-like EPCs by flow cytometry} Angioblast-like EPCs was quantified from peripheral blood mononuclear cells (PBMCs) isolated through density gradient medium with Ficoll-Paque Plus (GE Healthcare, Uppsala, Sweden) and stored at $-80{ }^{\circ} \mathrm{C}$ for 2 to 6 weeks. After thawing, the cells were incubated with 7AAD (Southern Biotechnology Associates Inc., Alabama,
USA), anti-KDR-APC (R \& D Systems, Inc., Minnesota, USA), anti-CD34-FITC (Southern Biotechnology Associates Inc.) and anti-CD133-PE (Miltenyi Biotec, California, USA) for $40 \mathrm{~min}$. The quantification of EPCs was performed using a FACS Canto II cytometer (BD Becton Dickinson, California, USA). EPCs were defined as 7AAD-negative, CD34-positive, CD133-positive and KDR-positive lymphmononuclear cells [13]. The percentage of viable cells (7AAD-negative) were similar between patients and controls (50.1 (11.4)\% vs 51,0 (14.1)\%, respectively; $p=0.684)$.

Analyzes were performed using the Flow-Jo software program (Oregon, USA) acquiring on average, 450,000 events for each sample. The technique of fluorescence minus one (FMO) was used for the final analysis. The EPCs quantification was presented as a percentage of the absolute number of EPCs among viable lymphomononuclear cells.

\section{Quantification of monocytic EPCs by cell culture}

Monocytic EPCs was quantified according the literature [13]. PBMCs were incubated in 6-well plates coated with fibronectin (BD - Becton Dickinson) for $48 \mathrm{~h}$ at $37{ }^{\circ} \mathrm{C}$. Each well contained $5 \times 10^{6}$ PBMCs suspended in $2 \mathrm{~mL}$ of Endocult medium (Stemcell Technologies, Washington, USA) supplemented with penicillin G streptomycin + amphotericin B (Invitrogen, California, USA). After incubation, the supernatant was aspirated, and a new cell count was performed and $1 \times 10^{6}$ cells were added in fibronectin-coated plates with 24 wells (BD - Becton Dickinson) suspended again in endothelial cell medium with antibiotic. Incubation was performed for another $72 \mathrm{~h}$ and stained with Giemsa 1\% (EMD Chemicals Inc., New Jersey, USA). CFU counts were carried out though of inverted microscope (CK2, Olympus, New York, USA). CFUs were characterized by cell clusters surrounded by elongated and spiculated cells and the results are presenting as number of CFUs.

\section{Confirmation of the endothelial lineage of CFUs}

To confirm the endothelial lineage of CFUs, the same procedure for EPCs culture was conducted, with two incubations performed in 48 and $72 \mathrm{~h}$, but in the last incubation fibronectin-coated plates with 24 wells were replaced by glass slides coated with fibronectin (BD BioCoat Fibronectin Coated Coverslips). After 72 hs incubation, coverslips were incubated with $12 \mu \mathrm{g} / \mathrm{mL}$ of 1,1'-dioctadecyl-3,3,3',3-tetramethyl-indocarbocyanine perchlorate labeled acetylated low-density lipoprotein (Dil-Ac-LDL) (Invitrogen) for $4 \mathrm{~h}$, fixed with methanol and incubated again with $10 \mu \mathrm{g} / \mathrm{mL}$ fluorescein isothiocyanate-conjugated Ulex europaeus agglutinin type I (FITC-UEA-I) (Sigma, Missouri, USA) [46]. Both are markers of endothelial lineage cells. Observation 
and image capture was performed by immunofluorescencespecific microscopy (Carl Zeiss, Oberkochen, Germany) and confirmed that the cells which constituted the UFCs were endothelial lineage cells.

\section{Quantification of VEGF}

VEGF dosage was performed by ELISA using a commercial kit (Human, VEGF Quantikine ELISA - R \& D Systems) according to manufacturer's manual.

\section{Statistical analysis}

Statistical Package for the Sciences (SPSS) version 15.0 (Chicago, USA) was used for statistical analysis. All data were considered having non-normal distribution by Kolmogorov and Shapiro-Wilk tests. Then, data were shown as median and interquartile range. Mann-Whitney $U$ test was used for comparisons regarding the quantification of EPCs and VEGF levels between groups of patients and controls as well as among subgroups of patients. Chi-square and Fisher's exact test were used for comparisons of categorical variables between subgroups of patients. Values of $P<0.05$ were considered significant and values between 0.05 and 0.10 were considered as a trend toward significance.

\section{Results}

The mean age of the patients and controls were comparable (32.5 (15.3) vs. 30.0 (5.3) years; $p=0.646)$. The mean time of diagnosis was $8.3 \pm 6.5$ years. Twenty-three $(76,7 \%)$ patients were hypertensive [47], 18 (60\%) were dyslipidemic [48] and 8 (27\%) were obese (47). As expected the frequency of these variables were higher than in controls (Table 1).

With respect to medication 16 patients were using statins (53.3\%), all were using acetyl salicylic acid (100\%) and 22 were on some antihypertensive medication (73.3\%). In relation to the specific treatment of arteritis, 23 patients (76.7\%) were using corticosteroids and 24 were using immunosuppressive drugs and five were using anti-TNF (Table 2). According to Kerr's criteria, nine patients were classified as having active disease (30\%).
No significant differences were found when comparing the subgroups of patients with and without disease activity in relation to hypertension, dyslipidemia, and use of statin, antihypertensive drugs, different doses of corticosteroids and different immunosuppressive drugs (Table 2).

\section{EPC count and VEGF dosage in patients and controls}

Flow cytometry showed that the proportion of EPCs between lymphomononuclear-viable cells was $0.0073 \%$ $(0.0081 \%)$ in patients and $0.0062 \%(0.0089 \%)$ in controls $(p=0.779)$. In cell culture the mean of colony-forming units of EPCs were 27.0 (42.3) in patients and 27.0 (20.5) CFUs in controls $(P=0.473)$.

There was no difference in VEGF levels between patients and controls (274.5 (395.5) $\mathrm{pg} / \mathrm{ml}$ vs. 243.5 (255.3) $\mathrm{pg} / \mathrm{ml}, p=0.460)$.

\section{EPCs and VEGF in patients with and without active disease} Quantification of EPCs in cell culture and by flow cytometry, as well as VEGF levels did not differ between patients with and without disease activity (Table 3 ).

\section{Medications}

Comparing the subgroup of patients with and without anti-TNF $\alpha$, no difference was found in relation to the quantification of monocytic EPCs and VEGF dosage. However, there was a tendency for patients using anti-TNF- $\alpha$ to have a higher number of angioblast-like EPCs (Table 4).

The use of methotrexate did not affect the quantification of EPCs by cell culture or VEGF dosage. However, we observed a tendency of patients using this medication to have a lower number of EPCs assessed by flow cytometry (Table 5).

There was no difference in the number of angioblast-like and monocytic EPCs when comparing subgroups of patients with and without use of leflunomide, statins and different doses of prednisone (data not shown).

Table 1 Demographic and clinical characteristics of the Takayasu's arteritis patients and controls

\begin{tabular}{llll}
\hline Variables & Takayasu's arteritis patients (30) & Controls (30) & $p$ \\
\hline mean age (years) & $(32.5(15.3)$ & $30.0(5.3)$ & \\
mean time of diagnosis (years) & $8.3 \pm 6.5$ & - & \\
Skin color & White:18 (60\%) & White: $20(66 \%)$ & Not White: $10(34 \%)$ \\
& Not White:12 (40\%) & - & 0,592 \\
patients with disease activity & 9 & $1(3 \%)$ & 0,01 \\
obesity (BMI > 30) & $8(27 \%)$ & $2(6 \%)$ & 0,001 \\
Hypertension & $23(76 \%)$ & $4(13 \%)$ & 0,001 \\
dyslipidemia & $18(60 \%)$ & & \\
\hline
\end{tabular}


Table 2 Frequency of hypertension, dyslipidemia, and use of medication in patients with and without Takayasu's arteritis activity

\begin{tabular}{|c|c|c|c|}
\hline Variables & $\begin{array}{l}\text { Without activity } N=21 \\
N(\%)\end{array}$ & $\begin{array}{l}\text { With activity } N=9 \\
N(\%)\end{array}$ & $p$ \\
\hline Hypertension & $16(76.2)$ & $07(77.8)$ & 1.00 \\
\hline Dyslipidemia & $12(57.1)$ & $06(66.7)$ & 0.704 \\
\hline Statins & $11(52.4)$ & 05 (55.6) & 1.00 \\
\hline ACE inhibitors & $10(47.6)$ & 05 (55.6) & 1.00 \\
\hline ARB & $02(9.5)$ & $01(11.1)$ & 1.00 \\
\hline Beta-blockers & $05(23.8)$ & $04(44.4)$ & 0.389 \\
\hline Calcium channel blockers & $05(23.8)$ & $03(33.3)$ & 0.666 \\
\hline Acetyl salicylic acid & $21(100)$ & $09(100)$ & 1.00 \\
\hline \multirow[t]{3}{*}{ Prednisone } & $16(76.2)$ & $07(77.8)$ & 0.166 \\
\hline & Dose $\leq 5$ mg: 06 (37.5) & Dose $\leq 5 \mathrm{mg}: 0$ & \\
\hline & Dose > 5 mg: 10 (62.5) & Dose > 5 mg: 07 (100) & \\
\hline \multirow[t]{4}{*}{ Immunosuppressive drugs } & $17(80,9)$ & $07(77,7)$ & 1,00 \\
\hline & Leflunomide: 06 (35) & Leflunomide: $05(71,4)$ & 0,225 \\
\hline & Methotrexate: 09 (53) & Methotrexate: 01(14,2) & 0,204 \\
\hline & Azathioprine: 02 (12) & Azathioprine: 01 (14,2) & 1,00 \\
\hline users of anti-TNF & $03(14,2)$ & $02(22,2)$ & 0,622 \\
\hline
\end{tabular}

$A C E$ angiotensin-converting enzyme, $A R B$ angiotensin receptor blocker

TNF tumor necrosis factor

\section{Hypertension and dyslipidemia}

There were no differences in the number of angioblast-like and monocytic EPCs, as well as the levels of VEGF when compared TA patients with and without hypertension and dyslipidemia (data not shown).

\section{Discussion}

Contrary to our expectation, and in opposition of the only one study in the literature [43], in the present study TA patients showed no significant difference compared to healthy women with respect to quantification of EPCs by flow cytometry, which evaluates angioblast-like EPCs or by cells culture with early growth, which evaluates monocytic EPCs. There was also no significant difference in relation to VEGF dosage between groups.

Table 3 EPCS and VEGF in Takayasu's arteritis patients with and without disease activity

\begin{tabular}{llll}
\hline Variables & $\begin{array}{l}\text { With activity } \\
N=09\end{array}$ & $\begin{array}{l}\text { Without activity } \\
N=21\end{array}$ & $p$ \\
& Median (IQ) & Median (IQ) & \\
\hline $\begin{array}{l}\text { Monocytic EPCs } \\
\text { (number of CFUs) }\end{array}$ & $27.0(40.0)$ & $27.0(43.0)$ & 0.929 \\
$\begin{array}{l}\text { Angioblast-like } \\
\text { EPCs (\%) }\end{array}$ & $0.0038(0.0067)$ & $0.0074(0.0118)$ & 0.326 \\
VEGF (pg/ml) & $279.0(625.0)$ & $272.0(295.0)$ & 0.657 \\
\hline
\end{tabular}

IQ Interquartil Range

EPCs endothelial progenitor cells

VEGF vascular endothelial growth factor
TA is a chronic inflammatory disease associated with elevated levels of several inflammatory cytokines [49, 50]. In our previous study TA patients with active disease showed increased TNF and IL-6 levels compared to inactive [51]. Many studies have evaluated EPCs in other rheumatic diseases. Holmen et al. (33) showed than the numbers of EPC colony-forming units are lower in patients with active granulomatosis with polyangiitis (GPA) as compared with those in remission and healthy individuals, probably caused by high levels of IL-8, epithelial neutrophil activating peptide-78 (ENA-78), macrophage inflammatory protein-1 $\alpha$ (MIP-1 $\alpha)$, and growth-related oncogene- $\alpha$ (GRO- $\alpha$ ) found in supernatants from patients with active disease. Patients with RA also have a lower number of EPCs than healthy individuals [9, 27, 28], however in RA, different than SLE, the cytokine responsible for the reduction of these cells seems to be TNF- $\alpha[52,53]$. Since TA is

Table 4 EPCs and VEGF in Takayasu's arteritis patients users and nonusers of anti-TNF

\begin{tabular}{llll}
\hline Variables & $\begin{array}{l}\text { With anti-TNF } \\
N=5 \\
\text { Median (IQ) }\end{array}$ & $\begin{array}{l}\text { Without anti-TNF } \\
N=25 \\
\text { Median (IQ) }\end{array}$ & $p$ \\
\hline $\begin{array}{l}\text { Monocytic EPCs } \\
\text { (number of CFUs) }\end{array}$ & $49.0(59.5)$ & $27.0(39.0)$ & 0.706 \\
$\begin{array}{l}\text { Angioblast-like } \\
\text { EPCs (\%) }\end{array}$ & $0.0108(0.0068)$ & $0.0038(0.0079)$ & 0.085 \\
VEGF (pg/ml) & $272.0(478.0)$ & $277.0(453.0)$ & 0.787 \\
\hline
\end{tabular}

IQ Interquartil Range

$E P C$ s endothelial progenitor cells

VEGF vascular endothelial growth factor 
Table 5 EPCs and VEGF in Takayasu's arteritis patients users and nonusers of methotrexate

\begin{tabular}{|c|c|c|c|}
\hline VARIABLES & $\begin{array}{l}\text { With methotrexate } \\
N=10 \\
\text { Median (IQ) }\end{array}$ & $\begin{array}{l}\text { Without methotrexate } \\
N=20 \\
\text { Median (IQ) }\end{array}$ & $p$ \\
\hline $\begin{array}{l}\text { Monocytic EPCs - } \\
\text { (number of CFUs) }\end{array}$ & 27.5 (34.3) & $27.0(43.2)$ & 0.746 \\
\hline $\begin{array}{l}\text { Angioblast-like } \\
\text { EPCs - (\%) }\end{array}$ & $0.0033(0.0065)$ & $0.0088(0.0098)$ & 0.061 \\
\hline VEGF (pg/ml) & 217.5 (419.8) & $293.0(442.3)$ & 0.286 \\
\hline
\end{tabular}

IQ Interquartil Range

$E P C s$ endothelial progenitor cells

VEGF vascular endothelial growth factor

a chronic inflammatory disease, where increased levels of TNF- $\alpha$ and other cytokines are also described $[49,50]$, we expected to find lower numbers of EPCs in this vasculitis.

The absence of the difference in the quantification of EPCs between TA patients and healthy controls can be explained, in part, by the balancing between intrinsic factors of Takayasu's arteritis, some of them that inhibit the formation of EPCs and others that stimulate their formation. Among the inhibiting factors, the most relevant are the chronic inflammatory nature of this disease $[49,50]$ and the high prevalence of hypertension and dyslipidemia. Regarding stimulatory factors, the most important is the chronic ischemic state observed in this arteritis [45]. Chronic ischemic states, such as those that occur in systemic sclerosis (SSc), promote the increase of EPCs [37-42]. Del Papa et al. [40, 41] reported a significant increase in VEGF, a cytokine-induced hypoxia, in SSc patients [15], which was associated with elevated levels of EPCs, thus showing the importance of hypoxia as a stimulator of EPCs. Although SSc and TA affect vessels with different caliber, ischemia/chronic hypoxia also can occur in TA, which could, in theory, contribute to the increase in EPCs. Usually TA patients with severe arterial stenosis/occlusion present collateral arteries formation that needs the presence of VEGF and EPCs.

The concomitant presence of inflammation and ischemia in TA may also explain the lack of difference in the levels of VEGF compared to controls. Inflammation, beyond reducing the number of EPCs, may be at least partially responsible by the reduction in VEGF serum levels, as observed in SLE patients [29]. Ischemia, in turn, can raise levels of this angiogenic cytokine, a situation found in systemic sclerosis $[40,41]$.

To assess the influence of inflammation on the quantification of EPCs, we analyzed subgroups of patients divided according to disease activity and no difference was observed between patients classified as active and inactive disease using Kerr's criteria. We know these criteria fail in the characterization of disease activity [44], but there is no criterion considered ideal. Therefore, the formation of subgroups may not have been adequate, which may have affected the outcome.

The Dogan study [43] found no difference of EPC between TA patients and controls, however they found a higher EPC number measured by cytometry, in subgroup of active disease comparing to controls. They also found higher levels of VEGF in TA patients with active disease than controls. This study presented a different patient's profile. Their patients were older, and smoker, diabetes and coronary disease were not excluded, for other hand our patients had higher frequency of dyslipidemia and hypertension. However, all these conditions are associated with lower EPC number and cannot explain the difference between studies. Although sample size and the methods to EPC measuring were similar, some difference between our and their study could be due to the ethnic variability. They did not evaluated the monocytic EPC by culture, than we could not compare with our result.

As several TA patients had factors known to influence the quantification of EPCs, we made comparative analysis between patients with and without hypertension and dyslipidemia, and no difference was observed between these subgroups. This results are according with Dogan study, which also did not find differences between patients with and without cardiovascular risk factor. One possible explanation for these results is that the majority of hypertensive and dyslipidemic patients were using medications, such as statins and ACE inhibitors, and studies have shown that the use of these medications increases quantification of EPCs [22, 23].

There was a tendency of increased angioblast-like EPCs in the subgroup of TA patients using anti-TNF $\alpha$ therapy, suggesting the importance of inhibition of this cytokine to increase EPCs. In RA patients, Ablin et al. [53] reported increased number of EPCs, assessed by cell culture, after infliximab use. Furthermore, Grisar et al. [52] demonstrated in vitro that cultured EPCs in the presence of TNFa showed reduced formation of CFUs.

The subgroup of TA patients using methotrexate showed a trend to have fewer angioblast-like EPCs when compared to patients without this medication. Only one study assessed the effect of methotrexate in cultured EPCs, observing an increase in apoptosis of those cells. [27]. This may be a possible mechanism to explain our data.

The limitations of our study were: a) a small sample due to the rarity of the disease; b) the use of frozen cells for cell counts, reducing the number of lymphomononuclearviable cells, however, there was no difference in the percentage of viable cells between patients and controls, and; c) the cross-sectional design to assess disease activity and effect of medication. Ideally, a prospective study would better evaluate the effect of these variables. 


\section{Conclusion}

In conclusion, no significant difference was found in the quantification of EPCs and VEGF levels in TA patients compared to controls, and no difference was observed between patients with active and inactive disease.

\section{Acknowledgements}

To our study group of autoimmune rheumatic diseases - Frederico Augusto Gurgel Pinheiro MD, Olívia Barbosa MD, Henrique Ataíde Mariz MD and Edgard Torres dos Reis Neto MD and to Neusa Pereira Silva,PhD.

\section{Funding}

This work was supported by FAPESP (São Paulo Research Foundation) [grant number 2009/15987-0].

\section{Authors' contributions \\ LSGM did a literature review, wrote the article and participated in flow cytometry and cell culture; ACDO did the clinical evaluation of patients; PSK developed the standardization of flow cytometry and cell culture; AWSS support in statistical analysis and bibliographic review; EIS idealized the project and did revision of the manuscript. All authors read and approved the final manuscript.}

\section{Ethics approval and consent to participate}

This study was approved by the Ethics Committee of the Federal University of São Paulo/Hospital São Paulo - CEP 1285/09.

\section{Consent for publication}

Not applicable.

\section{Competing interests}

The authors declare that they have no competing interests.

\section{Publisher's Note}

Springer Nature remains neutral with regard to jurisdictional claims in published maps and institutional affiliations.

Received: 4 July 2018 Accepted: 31 July 2018

Published online: 09 August 2018

\section{References}

1. Filer A, Nicholls D, Corston R, Carey P, Bacon P. Takayasu arteritis and atherosclerosis: illustrating the consequences of endothelial damage. J Rheumatol. 2001;28:2752-3

2. Hotchi M. Pathological studies on Takayasu arteritis. Heart Vessel. 1992:7:11-7.

3. Seyahi E, Ugurlu S, Cumali R, Balci H, Seyahi N, Yurdakul S, et al. Atherosclerosis in Takayasu arteritis. Ann Rheum Dis. 2006;65:1202-7.

4. Sharma S, Sharma S, Taneja K, Gupta AK, Rajani M. Morphologic mural changes in the aorta revealed by CT in patients with nonspecific aortoarteritis (Takayasu's arteritis). Am J Roentgenol. 1996;167:1321-5.

5. Shoenfeld Y, Gerli R, Doria A, Matsuura E, Cerinic MM, Ronda N, et al. Accelerated atherosclerosis in autoimmune rheumatic diseases. Circulation. 2005;112:3337-47.

6. Haque S, Mirjafari H, Bruce IN. Atherosclerosis in rheumatoid arthritis and systemic lupus erythematosus. Curr Opin Lipidol. 2008;19:338-43.

7. Souza AWS, Mariz HA, Neto ETR, Arraes AED, Silva NP, Sato El. Risk factors for cardiovascular disease and endothelin-1 levels in Takayasu arteritis patients. Clin Rheumatol. 2009:28:379-83.

8. Carvalho JF, Bonfá E, Bezerra MC, Pereira RMR. High frequency of lipoprotein risk levels for cardiovascular disease in Takayasu arteritis. Clin Rheumatol. 2009;28:801-5

9. Grisar J, Aletaha D, Steiner CW, Kapral T, Steiner S, Seidinger D, et al. Depletion of endothelial progenitor cells in the peripheral blood of patients with rheumatoid arthritis. Circulation. 2005;111:204-11.

10. Lee PY, Li Y, Richards HB, Chan FS, Zhuang H, Narain S, et al. Type I interferon as a novel risk factor for endothelial progenitor cell depletion and endothelial dysfunction in systemic lupus erythematosus. Arthritis Rheum 2007:56:3759-69.
11. Westerweel PE, Luijten RKMA, Hoefer IE, Koomans HA, Derksen RHWM, Verhaar MC. Haematopoietic and endothelial progenitor cells are deficient in quiescent systemic lupus erythematosus. Ann Rheum Dis. 2007;66:865-70.

12. Asahara T, Murohara T, Sullivan A, Silver M, van der Zee R, Li T, et al. Isolation of putative progenitor endothelial cells for angiogenesis. Science. 1997;275:964-7

13. Distler JH, Allanore Y, Avouac J, Giacomelli R, Guiducci S, Moritz F, et al. EULAR Scleroderma Trials and Research group. EULAR scleroderma trials and research group statement and recommendations on endothelial precursor cells. Ann Rheum Dis. 2009;68(2):163-8.

14. Werner N, Kosiol S, Schiegl T, Ahlers P, Walenta K, Link A, et al. Circulating endothelial progenitor cells and cardiovascular outcomes. N Engl J Med. 2005:353:999-1007.

15. Distler JH, Wenger RH, GassmannM KM, Hirth A, Gay S, et al. Physiologic responses to hypoxia and implications for hypoxia-inducible factors in the pathogenesis of rheumatoid arthritis [review]. Arthritis Rheum. 2004;50:10-23.

16. Kalka C, Masuda H, Takahashi T, Gordon R, Tepper O, Gravereaux E, et al. Vascular endothelial growth factor gene transfer augments circulating endothelial progenitor cells in human subjects. Circ Res. 2000;86:1198-202.

17. Yamaguchi J, Kusano KF, Masuo O, Kawamoto A, Silver M, Murasawa S, et al. Stromal cell-derived factor-1 effects on ex vivo expanded endothelial progenitor cell recruitment for ischemic neovascularization. Circulation. 2003;107:1322-8.

18. Vasa M, Fichtlscherer S, Aicher A, Adler K, Urbich C, Martin H, et al. Number and migratory activity of circulating endothelial progenitor cells inversely correlate with risk factors for coronary artery disease. Circ Res. 2001;89:E1-7.

19. Tepper OM, Galiano RD, Capla JM, Kalka C, Gagne PJ, Jacobowitz GR, et al. Human endothelial progenitor cells from type II diabetics exhibit impaired proliferation, adhesion, and incorporation into vascular structures. Circulation. 2002:106:2781-6.

20. Zhou B, Ma FX, Liu PX, Fang ZH, Wang SL, Han ZB, et al. Impaired therapeutic vasculogenesis by transplantation of OxLDL-treated endothelial progenitor cells. J Lipid Res. 2007;48:518-27

21. Kondo T, Hayashi M, Takeshita K, Numaguchi $Y$, Kobayashi $K$, lino S, et al. Smoking cessation rapidly increase circulating progenitor cells in peripheral blood in chronic smokers. Arterioscler Thromb Vasc Biol. 2004;24:1442-7.

22. Vasa M, Fichtlscherer S, Adler K, Aicher A, Martin H, Zeiher AM, et al. Increase in circulating endothelial progenitor cells by statin therapy in patients with stable coronary artery disease. Circulation. 2001;103:r21-6.

23. Min TQ, Zhu CJ, Xiang WX, Hui ZJ, Peng SY. Improvement in endothelial progenitor cells from peripheral blood by ramipril therapy in patients with stable coronary artery disease. Cardiovasc Drugs Ther. 2004;18:203-9.

24. Bhaskar A, Gupta R, Kumar L, Sharma A, Sharma MC, Kalaivani M, et al. Circulating endothelial progenitor cells as potential prognostic biomarker in multiple myeloma. Leuk Lymphoma. 2012;53(4):635-40.

25. Naik RP, Jin D, Chuang E, Gold EG, Tousimis EA, Moore AL, et al. Circulating endothelial progenitor cells correlate to stage in patients with invasive breast cancer. Breast Cancer Res Treat. 2008;107(1):133-8

26. Laufs U, Urhausen A, Werner N, Scharhag J, Heitz A, Kissner G, et al. Running exercise of different duration and intensity: effect on endothelial progenitor cells in healthy subjects. Eur J Cardiovasc Prev Rehabil. 2005;12:407-14.

27. Herbrig K, Haensel S, Oelschlaegel U, Pistrosch F, Foerster S, Passauer J. Endothelial dysfunction in patients with rheumatoid arthritis is associated with a reduced number and impaired function of endothelial progenitor cells. Ann Rheum Dis. 2006;65(2):157-63.

28. Egan CG, Caporali F, Garcia-Gonzalez E, Galeazzi M, Sorrentino V. Endothelial progenitor cells and colony-forming units in rheumatoid arthritis: association with clinical characteristics. Rheumatology (Oxford). 2008;47(10):1484-8

29. Denny MF, Thacker S, Mehta H, Somers EC, Dodick T, Barrat FJ, et al. Interferon-alpha promotes abnormal vasculogenesis in lupus: a potential pathway for premature atherosclerosis. Blood. 2007;110(8):2907-15.

30. Moonen JR, de Leeuw K, van Seijen XJ. Reduced number and impaired function of circulating progenitor cells in patients with systemic lupus erythematosus. Arthritis Res Ther. 2007;9(4):R84.

31. Baker JF, Zhang L, Imadojemu S, Sharpe A, Patil S, Moore JS, et al. Circulating endothelial progenitor cells are reduced in SLE in the absence of coronary artery calcification. Rheumatol Int. 2012;32(4):997-1002.

32. Katsuki Y, Sasaki K, Toyama Y, Ohtsuka M, Koiwaya H, Nakayoshi T, et al. Early outgrowth EPCs generation is reduced in patients with Buerger's disease. Clin Res Cardiol. 2011;100(1):21-7. 
33. Holmén C, Elsheikh E, Stenvinkel P, Qureshi AR, Pettersson E, Jalkanen S, et al. Circulating inflammatory endothelial cells contribute to endothelial progenitor cell dysfunction in patients with vasculitis and kidney involvement. J Am Soc Nephrol. 2005;16:3110-20.

34. Závada J, Kideryová L, Pytlík R, Vanková Z, Tesar V. Circulating endothelial progenitor cells in patients with ANCA-associated vasculitis. Kidney Blood Press Res. 2008;31(4):247-54.

35. Kuroi A, Imanishi T, Suzuki H, Ikejima H, Tsujioka H, Yoshikawa N, et al. Clinical characteristics of patients with Kawasaki disease and levels of peripheral endothelial progenitor cells and blood monocyte subpopulations. Circ J. 2010;74(12):2720-5.

36. Fadini GP, Tognon S, Rodriguez L, Boscaro E, Baesso I, Avogaro A, et al. Low levels of endothelial progenitor cells correlate with disease duration and activity in patients with Behçet's disease. Clin Exp Rheumatol. 2009;27(5):814-21.

37. Nevskaya T, Bykovskaia S, Lyssuk E, Shakhov I, Zaprjagaeva M, Mach E, et al. Circulating endothelial progenitor cells in systemic sclerosis: relation to impaired angiogenesis and cardiovascular manifestations. Clin Exp Rheumatol. 2008;26(3):421-9.

38. Avouac J, Juin F, Wipff J, Couraud PO, Chiocchia G, Kahan A, et al. Circulating endothelial progenitor cells in systemic sclerosis: association with disease severity. Ann Rheum Dis. 2008;67(10):1455-60.

39. Yamaguchi Y, Okazaki Y, Seta N, Satoh T, Takahashi K, Ikezawa Z, et al. Enhanced angiogenic potency of monocytic endothelial progenitor cells in patients with systemic sclerosis. Arthritis Res Ther. 2010;12(6):R205.

40. Del Papa N, Colombo G, Fracchiolla N, Moronetti LM, Ingegnoli F, Maglione $W$, et al. Circulating endothelial cells as a marker of ongoing vascular disease in systemic sclerosis. Arthritis Rheum. 2004;50(4):1296-304.

41. Del Papa N, Cortiana M, Comina DP, Maglione W, Silvestri I, Maronetti Mazzeo L, et al. Endothelial progenitor cells in systemic sclerosis: their possible role in angiogenesis. Reumatismo. 2005;57(3):174-9.

42. Tinazzi E, Dolcino M, Puccetti A, Rigo A, Beri R, Valenti MT, et al. Gene expression profiling in circulating endothelial cells from systemic sclerosis patients shows an altered control of apoptosis and angiogenesis that is modified by iloprost infusion. Arthritis Res Ther. 2010;12(4):R131.

43. Dogan S, Piskin O, Solmaz D, Akar S, Gulcu A, Yuksel F, et al. Markers of endothelial damage and repair in Takayasu arteritis: are they associated with disease activity? Rheumatol Int. 2014;34:1129-38.

44. Arend WP, Michel BA, Bloch DA, Hunder GG, Calabrese LH, Edworthy SM, et al. The American College of Rheumatology 1990 criteria for the classification of Takayasu arteritis. Arthritis Rheum. 1990;33:1129-34.

45. Kerr GS, Hallahan MS, Giordano J, Leavitt RY, Fauci AS, Rotten M, et al. Takayasu arteritis. Ann Intern Med. 1994;120:919-29.

46. Churdchomjan W, Kheolamai P, Manochantr S, Tapanadechopone P, Tantrawatpan C, U-pratya Y, et al. Comparison of endothelial progenitor cell function in type 2 diabetes with good and poor glycemic control. BMC Endocr Disord. 2010;10:5.

47. Malachias MVB, Barbosa ECD, Martim JF, et al. 7th Brazilian guideline of arterial hypertension. Arq Bras Cardiol. 2016;107(3 Suppl 3):79-83.

48. Xavier HT, Izar MC, Faria Neto JR, et al. V Brazilian guidelines on dyslipidemia and the prevention of atherosclerosis. Arq Bras Cardiol. 2013;101(4 Suppl 1):1-20

49. Tripathy NK, Chauhan SK, Nityanand S. Cytokine mRNA repertoire of peripheral blood mononuclear cells in Takayasu's arteritis. Clin Exp Immunol. 2004;138:369-74.

50. Park MC, Lee SW, Park YB, Lee SK. Serum cytokine profiles and their correlations with disease activity in Takayasu's arteritis. Rheumatology (Oxford). 2006;45(5):545-8.

51. Arraes AED, Souza AWS, Mariz HA, et al. F-Fluorodeoxyglucose positron emission tomography and serum cytokines and matrix metalloproteinases in the assessment of disease activity in Takayasu's arteritis. Rev Bras Reumatol. 2016:56(4):299-308.

52. Grisar J, Aletaha D, Steiner CW, Kapral T, Steiner S, Säemann M, et al. Endothelial progenitor cells in active rheumatoid arthritis: effects of tumour necrosis factor and glucocorticoid therapy. Ann Rheum Dis. 2007;66:1284-8.

53. Ablin JN, Boguslavski V, Aloush V, Elkayam O, Paran D, Caspi D, et al. Effect of anti-TNF alpha treatment on circulating endothelial progenitor cells (EPCS) in rheumatoid arthritis. Life Sci. 2006; 17;79(25):2364-9

Ready to submit your research? Choose BMC and benefit from:

- fast, convenient online submission

- thorough peer review by experienced researchers in your field

- rapid publication on acceptance

- support for research data, including large and complex data types

- gold Open Access which fosters wider collaboration and increased citations

- maximum visibility for your research: over $100 \mathrm{M}$ website views per year

At BMC, research is always in progress.

Learn more biomedcentral.com/submissions 